European Journal of Business and Innovation Research

Vol.8, No.5,pp1-22, August 2020

Published by ECRTD-UK

Print ISSN: 2053-4019(Print), Online ISSN: 2053-4027(Online)

\title{
THE EFFECT OF NON FINANCIAL MEASURES, INDEPENDENT BOARD OF COMMISSIONERS, AND AUDIT QUALITY AGAINST FIRM VALUE, WITH COST OF EQUITY AS A MODERATING VARIABLE
}

\author{
Taty Sariwulan \\ Student Doctoral Program Faculty of Economics and Business, Universitas Trisakti, \\ Indonesia, Lecturer in Accounting Departement, Faculty of Economics and Business, \\ Universitas Pasundan, Indonesia
}

Titik Aryati

Faculty of Economics and Business, Universitas Trisakti, Indonesia

\begin{abstract}
This study aims to analyze the effect of non-financial measures, independent board of commissioners, and audit quality on firm value, with the cost of equity as a moderating variable. The method used in this research is descriptive and verification methods. The data source is secondary data from the annual reports of manufacturing companies in the 20132016 period which are listed on the Indonesia Stock Exchange as many as 97 companies with 388 companies. The results showed that there are non-financial measures of customer perspective and internal process perspective, independent board of commissioner, and audit quality significantly influence firm value. Cost of equity as a moderating variable makes the influence of the independent board of commissioner weak against firm value. While the growth and learning perspective variables do not really affect the firm value. Cost of equity strengthens the influence of non-financial measures customer perspective on firm value, while in the internal process perspective, growth and learning of non-financial measures and audit quality are weak. The cost of equity will strengthen variables that can support the wishes of shareholders and will weaken variables that are independent of board of commissioner and audit quality. Other results require large costs to increase firm value. Firm value can be increased by increasing non-financial activities, the number of independent board of commissioner shares and conducting audit quality by reducing the amount of cost of equity that can weaken the value of firm value.
\end{abstract}

KEYWORDS: non financial measures, independent board of commissioner, audit quality, firm value, cost of equity

JEL Classification: L11 : M41

\section{INTRODUCTION}

Firm value has an important role for the company because high company value will be followed by high welfare for the company's stakeholders. According to Sujoko and Soebiantoro (2007), the results of the evaluation of shareholders on the success of the company and the relationship with changes in stock prices reflect is the value of the company. Shareholders must ensure that the stock exchange that occurs will provide a positive return to the company (Zuhroh, 2019). Therefore, firm value is one measure of success over the implementation of financial functions in the company. A good measure of firm value begins with investors' trust in a company that 
European Journal of Business and Innovation Research

Vol.8, No.5,pp1-22, August 2020

Published by ECRTD-UK

Print ISSN: 2053-4019(Print), Online ISSN: 2053-4027(Online)

the funds they invest in are safe and are expected to provide good returns. This also reflects that companies that have high firm value have the ability to pay all their obligations and avoid risk (Zuhroh, 2019).

Companies that have high firm values will get the attention of investors, banks and the government so that the company's value increases. Companies must pay attention to economic and social activities can have an impact on firm value both positive and negative. Economic or social activities that have a positive impact include dividend policy (Handriani \& Robiyanto, 2018), investment decisions (Handriani \& Robiyanto, 2018), funding policies (Handriani \& Robiyanto, 2018), profitability (Indriyani, 2017; Rahayu \& Sari, 2018; Utomo, 2016; Zuhroh, 2019), Leverage (Utomo, 2016), Corporate Social Responsibility (CSR) (Utomo, 2016), earning quality (Rahayu \& Sari, 2018), tax planning (Khaoula \& Moez, 2019), logistics service standardization (LSS) (Tan, Yan, \& Chan, 2019). Economic or social activities that have a negative impact on firm value include liquidity policies (Indriyani, 2017), size (Indriyani, 2017; Rahayu \& Sari, 2018; Utomo, 2016; Zuhroh, 2019), Debt to Equity Ratio (DER) (Agustina \& Ardiansari, 2015), Leverage (Rahayu \& Sari, 2018), protection of directors (Aguir \& Aguir, 2019), CEOs friendship (Fan, Boateng, King, \& MacRae, 2019) independence and diversity of the board of commissioners (Khaoula \& Moez, 2019), dual function of CEO (Khaoula \& Moez, 2019), foreign investment (Likitwongkajon \& Vithessonthi, 2020).

Firm value of a company is related to finance. However, matters related to non-financial matters also need to be taken into account including political policies (Bhandari, Rose, \& Wilson, 2019), culture (Grundy et al., 2019), society (Grundy et al., 2019), personal attribute (Grundy et al., 2019), professional experience (Grundy et al., 2019), intellectual effort (Grundy et al., 2019), financial interests (Grundy et al., 2019), conflicts of interest (Grundy et al., 2019), currency selection (Harasztosi \& Kátay, 2017), competencies (Titko \& Shina, 2017), dan and human resource reward system (Titko \& Shina, 2017). Va der Stede et. al. (2006) states that companies will be assisted in implementing and managing new innovations if non-financial performance is measured (Ahmad \& Zabri, 2016). As with the Heat Combined Heat and Power (CHP) project that occurred in America where many CHP projects are economically viable but are stopped by non-financial barriers (Bhandari et al., 2019), currency selection for import and export transactions affects performance sales in companies in Hungary (Harasztosi \& Kátay, 2017), and improvement and development of competencies, operational efficiency of human resources, remuneration and motivation affect banking value in Latvian European countries (Titko \& Shina, 2017).

In addition, one of the economic activities that affects firm value is an independent board (Zhu, Ye, Tucker, \& Chan, 2016). Independent boards including directors, managers and commissioners sometimes give a better voice in determining management decisions (Zhu et al., 2016). Therefore, independent boards such as directors, managers and commissioners determine the policy in the company in making decisions, such as the national sports federations (NSF) organized sports in Germany where the commissioner's policy can stop immoral acts in the German NSF (Hartmann-Tews, Bartsch, Wagner, \& Rulofs, 2019), in USA companies from 1999 - 2015 where companies that apply Lead Independent Directors (LID) can improve firm value and quality of corporate governance (Lamoreaux, Litov, \& Mauler, 2019), and a policy has a negative impact on company performance because of the ambiguity 
European Journal of Business and Innovation Research

Vol.8, No.5,pp1-22, August 2020

Published by ECRTD-UK

Print ISSN: 2053-4019(Print), Online ISSN: 2053-4027(Online)

of the board's independence (Cavaco, Crifo, Reberioux, \& Roudaut, 2017). This shows that the firm value is influenced by an independent board or commissioner.

So that firm value is always well controlled, the company must conduct an audit. Audits are conducted to maintain the quality of company performance and are often called quality audits (Aobdia, 2019; Appiah, 2020; Azizkhani, Daghani, \& Shailer, 2018). Several studies related to quality audits conducted include the implementation of quality audits that do not have an impact on improving the quality of education in private universities in Oman (Kooli, 2019), the price and quality of auditing firms and auditors influencing the results of quality audits (MohammadRezaei, Mohd-Saleh, \& Ahmed, 2018; Singh, Singh, Sultana, \& Evans, 2019), conducting audits carried out on environmental, social, and management costs is quite high (Appiah, 2020), the selected auditors must meet indicators related to requirements as auditors (Dickins, Johnson-Snyder, \& Reisch, 2018), audit firms that merge can benefit clients and not degrade the quality of audits (Lai, 2019), government policies can affect the quality of audits (Azizkhani et al., 2018), and Audit company ratings affect the results of the audit (MohammadRezaei et al., 2018). This shows that the cost and quality of the auditing company can affect audit quality.

The cost of equity of a company can be influenced by firm value (A. Gupta, Raman, \& Shang, 2018; K. Gupta, Krishnamurti, \& Tourani-Rad, 2018). Botosan (2006) states that the minimum return required by investors / shareholders to be willing to reinvest their capital into the company is the cost of equity (Falah \& Meiranto, 2017). Therefore, the cost of equity affects the financial companies that affect firm value as in research related to the cost of equity in domestic companies that are smaller than outside companies (Boubaker, Boubakri, Grira, \& Guizani, 2018), Corporate Social Responsibility (CSR) activities (Breuer, Müller, Rosenbach, \& Salzmann, 2018), on the application of management's responsibility for financial reports (MRF) (Bangmek, Yodbutr, \& Thanjunpong, 2018), investment in information technology (Dow, Watson, \& Shea, 2017), and control of shareholders (Guo, Li, Jiao, \& Wang, 2019). Based on this, the amount of cost of equity affects the firm value of a company.

This study will conduct an analysis related to the influence of non-financial measures, independent board of commissioners, and audit quality on firm value in companies in the period 2013-2016, is listed on the Indonesian stock exchange (BEI), and is engaged in manufacturing. Some research related to companies listed on the IDX include the application of Islamic (Sharia) law, corporate governance, and growth opportunities affecting dividend policy (Imamah, Lin, Suhadak, Handayani, \& Hung, 2019), efficiency of the Indonesian stock exchange (Andrianto \& Mirza, 2016), the behavior of price setting on the Indonesian stock exchange is contributed by the credit risk market (Sharma, Thuraisamy, Madyan, \& Laila, 2019), and and research related to return on equity (ROE), Size, composition and return of assets (ROA) ) that affects good corporate governance (GCG) in companies (Makonah, Cahaya, \& Riwayati, 2016). Therefore, this research is new in analyzing the factors that influence firm value in companies listed on the Indonesian stock exchange consisting of nonfinancial measures, independent board of commissioners, and audit quality engaged in manufacturing. In addition, another recent thing is the cost of equity is a moderating variable with the aim of whether there is an increase and decrease in other variables due to the cost of equity. 
European Journal of Business and Innovation Research

Vol.8, No.5,pp1-22, August 2020

Published by ECRTD-UK

Print ISSN: 2053-4019(Print), Online ISSN: 2053-4027(Online)

\section{LITERATURE REVIEW AND DEVELOPMENT OF HYPOTHESES}

\section{Literature Review \\ Agency theory}

Agency theory developed by Michael Johnson in Achmad Daniri, 2006 views that corporate management as an "agent" for company owners who act in their own interests with full awareness (Murwaningsari, 2009). Agency problems arise, including if management (agents) do not own the company's ordinary shares. With this condition, agents do not try to maximize company profits and agents try to take advantage of the burden borne by shareholders, in the form of increased wealth and satisfaction and company facilities, including manipulating the company's financial statements to get prizes or bonuses that are calculated based on achieving financial numbers that are presented in the Financial Statements. Agency theory wants to solve problems arising from agency relationships, namely when shareholders cannot know for certain whether agents have acted appropriately, and when shareholders have a different view of riskrelated agents (Kovermann \& Velte, 2019; Sofia, 2019). Agency theory stipulates that opposing interests of shareholders (principals) and managers (agents) can trigger conflicts and will disrupt the smooth running of the company (Rodriguez-Fernandez, 2016). The separation between company owners and managers in agency theory results in the risk of conflict that can affect the quality of the profits generated. Management tends to prepare earnings reports in accordance with specific objectives and interests and not in the interests of shareholders. Therefore, a control mechanism is needed so that it can align the differences of interests between the two parties (Wati \& Putra, 2017). This happened to several manufacturing companies in Indonesia in 2010 - 2012 which were listed on the stock exchange where discretionary accruals (Asti Awalia, 2014), Estonian public-private water companies showed that there was a debate over public-private profit and the highest authority that decided this matter with the aim of seeking excessive profits (Peda \& Vinnari, 2019) making it vulnerable to intervention and litigation from the community and government (Nafisah \& Meiranto, 2017).

\section{Signalling Theory.}

Miller-Modigliani or MM (2013) assumes that investors have the same information as the company's internal managers about the company's prospects (Alifani \& Nugroho, 2019), but the reality in economics and finance shows that internal managers have better and more up-to-date information about company condition compared to investors (Soleman H. Abdul Kahar, 2008). This allows asymmetric information to affect the investor in evaluating the company's situation, especially related to the company's value. Given this condition, investor valuations of company shares are low and this is referred to as pooling equilibrium, because companies are pooled for the whole company, which causes companies with high value to be integrated with low value companies. Therefore, behavior when two parties namely managers and company owners have access to different information is the theory of signaling (Connelly, Certo, Ireland, \& Reutzel, 2011). Signaling theory assumes that the information obtained by each party is not the same, which means that the signaling theory is related to asymmetric information. In this case the company manager must provide financial statement information and signals to all interested parties as users of financial statements (Connelly et al., 2011). This signal theory helps parties to avoid asymmetric information, and presents quality financial reports, so that interested parties trust and trust the financial information reported by the company. This is where the importance of the opinion of independent parties who provide opinions about financial 
European Journal of Business and Innovation Research

Vol.8, No.5,pp1-22, August 2020

Published by ECRTD-UK

Print ISSN: 2053-4019(Print), Online ISSN: 2053-4027(Online)

statements presented by company managers. When this happens, quality financial information will have an impact on the decision of stock investors in the stock exchange because it is supported by good signals in the future.

\section{Non Financial Measures}

Non-financial measures used in this study are the balanced scorecard. The Balanced Scorecard is a method for measuring organizational performance from a perspective consisting of learning and growth, internal processes, customers, and finance. On the concept of learning and growth with regard to how organizations can continue to create value, internal process perspectives relate to determining what excels in the organization, customer perspectives relate to customer perspectives, and financial perspectives relating to how organizations are viewed by shareholders (Kaplan \& Norton, 2001). The basic idea of the Balanced Scorecard is that learning and growth will improve internal business processes where this is expected to increase customer satisfaction which can ultimately improve financial results. The Balanced Scorecard is not only the achievement of certain goals but emphasizes improvement because the organization does not continue to increase it will be inferior to competitors (Kaplan, 2012). With the Balanced Scorecard, corporate decision makers can measure and manage the company's business so that trust can be created from current and future customers. However decision makers must build and enhance internal capabilities, improve the ability of human resources, systems, and procedures needed to improve company performance (Okoye, Odum, \& Odum, 2017).

\section{Independent Board of Commisioner}

Part of the corporate governance structure is an independent commissioner (Amin, Djuminah, \& Suhardjanto, 2017; Zulfikar, May, Suhardjanto, \& Agustiningsih, 2017). According to KNKG (2006), a company must have a board of commissioners that is not affiliated with management, another board of commissioners, shareholders and this board must be free from business or matters that can affect its competence. The board of commissioners is an independent board of commissioners. The board of commissioners must act independently or solely for the benefit of the company. Personnel who are placed in independent commissioners must be truly independent of all things that can influence decisions made (Indonesia, 2007). Zahra and Pearce (1989) stated that independent commissioners function to oversee management activities, encourage performance reports, and improve performance in making policies so that corporate strategies can be achieved (Gumanti \& Prasetiawati, 2012). According to the OECD (2004), in realizing the effectiveness of company management supervision an independent commissioner is needed. This causes good relations and trust of stakeholders to be maintained and managers can work optimally in increasing the value of the company in a sustainable manner. Therefore, independent commissioners are individuals who oversee company management and act to protect the interests of stakeholders (Johnston, 2004).

\section{Audit Quality}

The results of the audit must be quality. The quality is obtained from the characteristics of the activities and audit results compared to auditing standards and quality control. Auditing standards become a reference for an auditor in carrying out duties and responsibilities. How well the company's work is completed against established criteria shows the quality of an audit. When auditing a company's financial statements, for example, the auditor can find several 
European Journal of Business and Innovation Research

Vol.8, No.5,pp1-22, August 2020

Published by ECRTD-UK

Print ISSN: 2053-4019(Print), Online ISSN: 2053-4027(Online)

possible violations and report them. This shows the quality of the audit. However, auditors must be guided by audit standards and their code of ethics. Based on the Public Accountant Professional Standards (SPAP) audits conducted by auditors have met and are relevant to the applicable provisions and standards, the audit is said to be of quality. (Tulli, 2014).

\section{Cost of Equity}

The rate of return expected by investors when investing their money in a company is a cost of equity. One of the measurements used to measure the cost of equity is the Capital Asset Pricing Model (CAPM). Measurement with CAPM is an adjustment of company-specific risk through a beta which measures the response of the company's stock price to its overall movement in the market. This is because a high correlation between stocks and markets increases the volatility of the market portfolio, and this is the data needed by high profit investors to hold the shares. What happens, the expected return exceeds the market return due to high beta stocks (Koller, Goedhart, \& Wessels, 2015). According to McKinsey (2015) in calculating CAPM there are three dominating variables namely risk free rate, risk premium, and beta (Koller et al., 2015). The rate of return of investment assets is risk free rate risk free rate. In developing countries, risk free rates are more difficult to predict than in developed countries. There are 3 (three) main problems that arise in the risk free rate, namely (1) the majority of government debt in developing countries, in fact, is not risk free (2) long-term government bonds that are actively traded with liquidity that are quite difficult to find (3 ) The US dollar, European euro or Japanese yen is a currency that is often used for long-term debt, so it is not appropriate to discount local cash flows (Koller et al., 2015). Risk premium is added to long-term government bonds to estimate future market returns by combining interest rates and inflation. If you want to properly estimate your risk premium track, you need statistical sophistication. Many argue that the risk premium has decreased over time, but a simple regression analysis does not confirm this, and therefore a lot of data is needed to improve quality estimates (Koller et al., 2015). Beta is a relative index of market risk. Practitioners calculate that beta is potentially distorted by the fact that indexes in emerging markets will rarely represent a diversified economy so it's not only inconsistent from the perspective of global investors in local market indices. The average beta size in European and US retail companies is around 0.7. Beta is much higher in the range of 0.7 to 1.0 in Latin America. The ConsuCo beta estimate itself is 0.81 which is above the US and European Union groups (Koller et al., 2015).

\section{Firm Value}

Company Value (FV) is the value of an economy that reflects the trade value of a business. The main purpose of the organization is to maximize the value of the company. Managerial decisions on earnings will take into account the long term that will occur in the value of the company. The company's goal is to maximize profits and this must be understood as maximizing the value of current and future earnings. Brigham \& Houston (2001) defines developing companies, corporate value as the value given to financial market management and corporate organizations where this value is represented by the value of outstanding shares which is the market's perception of the company's performance and sustainability (Sabrin, Sarita, Takdir, \& Sujono, 2016). Proxy measurements for the company value of most researchers use Tobin's Q (Pacheco-de-Almeida, Hawk, \& Yeung, 2007). Brigham \& Houston (1999), and Wahyudi and Prawesti (2006) use a ratio of market value proxies to book values. 
European Journal of Business and Innovation Research

Vol.8, No.5,pp1-22, August 2020

Published by ECRTD-UK

Print ISSN: 2053-4019(Print), Online ISSN: 2053-4027(Online)

Market value to book value of equity is a comparison or ratio of market value (Fu, Parkash, \& Singhal, 2017).

\section{Development of Hyphoteses}

\section{Non Financial Measures on Firm Value}

In this study, researchers analyzed non-financial measures using a non-financial balanced scorecard perspective measurement. According to Kaplan and Norton (2004), BSC is a system that uses learning and growth (knowledge, skills, and systems) needed by human resources to improve the company's internal processes (innovation and building effective and efficient strategic capabilities) that provide specific value to the customers, which will ultimately lead to financial improvements (higher shareholder value) (Kaplan, 2012). The customer perspective determines the market segments and customers that are targeted by the company. Furthermore, managers must also determine a good measurement tool to measure the performance of each company's goals in an effort to achieve financial targets. Then if a company wants to maintain its goals in the long run the executive manager must create and maintain a product / service of good value (Kaplan, 2012). The study of Wu and Chen revealed that the company's financial performance was positively influenced by the customer's perspective which had an impact on increasing the value of the company (Wu \& Chen, 2011). Based on this, the first hypothesis of this study:

H1: Firm value is positively influenced by the customer's perspective.

The process that occurs within a company to provide a measure of the performance of a company to maintain production processes and market segments that satisfy shareholders and the company is shown by the perspective of internal business processes (Kaplan, 2012). Wu and Chen's research revealed that the company's financial performance is positively influenced by the perspective of internal business processes that have an impact on increasing company value (Wu \& Chen, 2011). Based on this, the second hypothesis of this study:

H2: Firm value is positively influenced by the perspective of internal business processes.

This perspective provides a relationship for the achievement of the three previous perspectives, to produce growth and good learning it is important for a company to think about investing not only in equipment to produce products / services, but also innovating growth and learning in human resources, systems and procedures in the company. Research by Wu and Chen (2011) revealed that financial perspective is positively influenced by learning and growth perspectives (Wu \& Chen, 2011). Huang, Chu, and Wang (2007) conducted a survey of international tourist hotels in China and concluded that learning and growth had a positive impact on the increase in hospitality finance (Huang, Chu, \& Wang, 2007). In addition, from the results of the chief financial research in 43 New Zealand companies, Shanahan, and Gage (2005), better service / quality, lower recruitment costs, stronger finance was obtained by minimizing staff turnover at the company (Lord, Shanahan, \& Gage, 2006). Based on this, the third hypothesis of this study is:

H3: Firm Value is positively influenced by the perspective of growth and learning. 
European Journal of Business and Innovation Research

Vol.8, No.5,pp1-22, August 2020

Published by ECRTD-UK

Print ISSN: 2053-4019(Print), Online ISSN: 2053-4027(Online)

\section{The Effect of Independent Board of Commissioner on Firm Value}

In a large company there is usually a board of commissioners that determines the company's policies. This board consists of the company's internal commissioners and independent commissioners. Specifically, the independent commissioner aims to oversee corporate governance and encourage more professional management actions so that the company can run well. With the existence of an independent commissioner, the conflicts that occur between company owners and managers can be minimized. In addition, the existence of an independent commissioner is expected to be an oversight mechanism that can run effectively and in accordance with statutory regulations. In general, companies that commit fraud have a low number of independent directors. Boediono (2005) states that actions in determining company profits are influenced by the composition of the board of commissioners (Dananjaya \& Agus Ardiana, 2016). The board of commissioners originating from outside the company has a tendency to reduce profits and increase the effectiveness of the board of directors' supervision of the financial statements of management. This is in accordance with research conducted by Chtourou et al. (2001) and Xie et al. (2003) (Hanim et al., 2008), Midiastuty dan Machfoedz (2003) (Jao \& Pagalung, 2011), dan Cornett et al. (2006) (Gumanti, Nastiti, \& Lestari, 2016). However, according to Ujiyantho and Pramuka (2007), the independent board of commissioners only tends to have a positive effect on company profits (Jao \& Pagalung, 2011). Boediono (2005) states that the number of independent commissioners is only possible to fulfill the regulations made, not to improve corporate governance mechanisms (Dananjaya \& Agus Ardiana, 2016). The performance of the board of commissioners that did not increase or decrease was due to the presence of majority shareholders who fully held company policy. Therefore, there is inconsistency in the results of research between the influence of independent commissioners on company value. This is confirmed by the results, research Kaplan et. all. (1990) and Millstein et. all. (1998) which proves that company value will increase due to the professional abilities of independent commissioners (Setiadi, Rahmawati, Suhardjanto, \& Djuminah, 2017) while research by Yermack (1996), Agrawal and Knoeber (1996), Subrahmanyam, Rangan, and Rosenstein (1997), and Bhagat et. all. (1999) got the opposite result where the value of the company dropped due to the presence of an independent commissioner (Setiadi et al., 2017; Wulandari, 2006). Even the research of Hermalin et. all (1991), Vafeas et. all. (1998), and Bhagat et. all. (2002), independent commissioners had no effect at all on the value of the company (Setiadi et al., 2017). However, based on this, the fourth hypothesis of this study is:

H4 : Firm Value is positively influenced by the Independent Board Commissioner.

\section{The Effect of Quality Audit on Firm Value}

Meutia (2004) states that the audit is a process to reduce the misalignment of information that exists between managers and other parties as well as a kind of endorsement of financial statements (Christiani \& Nugrahanti, 2014). Audits are conducted to maintain the quality of company performance and are often called audit quality (Aobdia, 2019; Appiah, 2020; Azizkhani et al., 2018). The use of high quality auditors will reduce the opportunity for companies to cheat in presenting inaccurate information to the public (MohammadRezaei et al., 2018) . Thus potential investors have non-misleading information regarding the company's future development and improvement. Based on this, the fifth hypothesis of this study is: 
European Journal of Business and Innovation Research

Vol.8, No.5,pp1-22, August 2020

Published by ECRTD-UK

Print ISSN: 2053-4019(Print), Online ISSN: 2053-4027(Online)

H5: Firm value is positively influenced by Audit Quality.

\section{The Effect of Moderating Cost Of Equity on Non Financial Disclosure Against Firm Value}

Every company offering its shares through the capital market must disclose all business financial information. It is better if management also discloses non-financial information. Information disclosed by management or company is one of the factors that influence the cost of equity. Companies that do not provide adequate cost of equity by some investors are seen as risky financial statements (Nurjanati \& Rodoni, 2015). According to Clarkson et al. (1996: 69.79), if an investor assesses a high-risk company based on the financial statements produced, then the return value expected by investors is also high, which in turn will lead to high cost of equity that must be issued by the company (Nurjanati \& Rodoni, 2015). In this study, nonfinancial disclosure uses the balance scorecard prefective variable. Based on this and its prefective variables, the sixth to eighth hypotheses of this study are:

H6: The customer's prefective effect on firm value is weakened by the Cost of equity.

H7: The effect of prefective internal business processes on firm value is weakened by the Cost of equity.

H8: The prefective effect of growth and learning on firm value is weakened by the Cost of equity.

\section{Moderating Cost of Equity on the Independent Board of Commissioner Against Firm Value}

According to Ashbaugh et al. (2004), the cost of equity capital is negatively affected by the composition of the independent board where the more boards come from outside, the more effective their supervisory function will be to minimize earnings management actions (Skaife, Collins, \& LaFond, 2011). If earnings management measures are reduced, agency risk will also be reduced and the cost of equity capital will be low (Sari, 2009). The decision of the Independent Board of Commissioner to improve company performance by implementing management's responsibility for financial reports (MRF) can reduce the cost of equity (Bangmek, Yodbutr, \& Thanjunpong, 2018), as well as if it decides to use technology information (Dow et al., 2017). Meanwhile, the Independent Board of Commissioner whose investment policies and system implementation are tightly controlled by shareholders can increase the value of cost of equity (Guo et al., 2019). Based on this, the ninth hypothesis of this study is:

H9: The influence of the Independent Board of Commissioner on Firm Value is weakened by the cost of equity.

\section{The Effect of Moderating Cost of Equity on Quality Audit on Firm Value.}

Companies that use high quality auditors will increase investor confidence in investing their funds in these companies (MohammadRezaei et al., 2018; Singh et al., 2019). Audit quality is considered to reduce the cost of equity capital because it can increase market liquidity such as increasing the volume of stock trading and with increasing volume of stock trading, this will increase the value of the company as well (Kirana, 2013). With quality audits, companies must use a management system and prepare facilities and infrastructure. This can reduce the value 
European Journal of Business and Innovation Research

Vol.8, No.5,pp1-22, August 2020

Published by ECRTD-UK

Print ISSN: 2053-4019(Print), Online ISSN: 2053-4027(Online)

of cost of equity (Bangmek et al., 2018; Dow et al., 2017). Based on this description, the research hypothesis is:

H10: The effect of Audit quality on Firm Value is weakened by the Cost of Equity.

\section{RESEARCH METHOD}

\section{Population and Methode}

Annual reports from 97 manufacturing companies in the period 2013-2016 were used as secondary data in this study. Based on the annual report there are 388 observations. All of these companies are listed on the Indonesia Stock Exchange. Manufacturing companies are one of the pillars of economic activity in Indonesia so it is interesting to be the object of research. Its existence is expected to be able to support efforts to achieve welfare in Indonesia. For this hope to be realized, serious efforts are needed in optimizing the existence of manufacturing companies as economic pillars in Indonesia. The purposive sampling method was used to determine the sample in this study with the following criteria: (1) Registered on the Indonesia Stock Exchange (IDX) (2) Publishing their financial statements in Rupiah; (3) Included in the manufacturing industry group which publishes annual and financial reports on December 31 during the observation period; and (4) Having complete data to support research.

This research model is a moderation regression analysis, with the following equation:

$$
\begin{aligned}
\mathrm{FV} & =\beta 0+\beta 1 \mathrm{PP}+\beta_{2} \mathrm{PPI}+\beta 3 \mathrm{PPP}+\beta 4 \mathrm{IBOC}+\beta 5 \mathrm{AQ}+\beta 6 \mathrm{PP} * \mathrm{COE}+\beta 7 \mathrm{PPI}{ }^{*} \mathrm{COE}+\beta \mathrm{PPP}^{*} \mathrm{COE} \\
& +\beta 9 \mathrm{IBOC} * \mathrm{COE}+\beta 10 \mathrm{AQ} \mathrm{COE}^{*}+\beta_{11} \mathrm{Size}+\beta 12 \mathrm{ROA}+\beta 13 \mathrm{Growth}+\beta 14 \mathrm{DER}+\varepsilon
\end{aligned}
$$

where FV: Firm Value, PP: Customer Perspective, PPI: Internal Process Perspective, PPP: Learning and Growth Perspective, IBOC: Independent Board Of Commissioner, AQ: Audit Quality, SIZE: Firm Size, ROA: Return On Assets, DER: Debt to Equity Ratio, COE: Cost of Equity, \&: error.

\section{Variabel}

$\mathrm{n}$ this study, firm value is the dependent variable. Measuring the performance of a company is important to do because it knows whether the firm value is good or bad. Firm value measurements in various studies can be measured by the company's operating performance and market performance. Measurement of company operating performance can be used to see the ability of a company that is seen in its financial statements. One method used to calculate company value is to use Tobin's Q, developed by James Tobin (1967). The reason for using Tobin's Q as a performance measurement is because Tobin's can be known by the company's market value that will reflect the future of a company such as current earnings and is believed to provide an overview of the market appraisal of a company (Ongkowibowo \& Hatane, 2015). The formula used to calculate company value is (total market value + total book value of liabilities) / total book value of assets (Ongkowibowo \& Hatane, 2015). Independent variables (X) in this study are Non financial measures, Independent Board of Commissioner , and Quality Audit. Independent variables that represent the size of the perspective of non-financial balanced scorecard, among others (1) for the customer perspective using income growth which is calculated as the difference between income in years $\mathrm{t}$ and $\mathrm{t}-1$ divided by income years $\mathrm{t}-1$ in research Ke (2008) and Wang et . all. (2013) (2) for the internal process perspective using 
revenue measures divided by the number of employees as employee productivity (3) for learning and growth using the salary ratio calculated as salary divided by income by proving customer satisfaction (Rabo, 2014). For independent board of commissioners, it is measured based on the percentage of independent commissioners, namely the number of members of the board of commissioners who are not affiliated with other boards, shareholders, directors, and free from all business relationships or others that can affect their ability to act independently (Vintilă \& Gherghina, 2013). Regarding audit quality, this is measured by 8 audit criteria consisting of audit size, co-statutory, audit opinion, audit lag, audit specialization, auditor size and co-statutory, audit tenure, experience. In addition, audits must be carried out by competent and independent auditors (Kirana, 2013). Related to Cost of Equity, this study uses measurements with the Capital Asset Pricing Model (CAPM) (Wibisono \& Handayani, 2015). The CAPM formula is: $\mathrm{EI}=\mathrm{Rf}+\mathrm{flu}(\mathrm{RM}$, $-\mathrm{Rf})$, where EI: Cost of Equity, Rf: risk-free asset return for period $t$, flu: beta stock I for period $t, R M$ : return on market portfolio for period $t$. Rf is a risk free rate that is proxied at a one-month SBI interest rate, in December. Flu is an unsystematic risk for stocks I proxy using beta calculated based on time series stock prices and $\mathrm{RM}$ is the return on the market portfolio for the year. The control variables in this study are Size (company size), Return On Assets (ROA), Growth and Debt to Equity Ratio (DER).

\section{RESULT AND DISCUSSION}

\section{A. Descriptive Statistics}

Statistical test results of the dependent, independent, moderating and control variables used can be seen in table 1 .

Table 1. Statistik Deskriptif

\begin{tabular}{rrrrrr}
\hline VARIABEL & N & MINIMUM & MAXIMUM & MEAN & STD. DEVIATION \\
\hline PP & 388 & -.99 & 18.18 & .23 & 1.28 \\
\hline PPI & 388 & 4.51 & 29.79 & 20.79 & 2.02 \\
\hline PPP & 388 & .00 & 1.27 & .41 & .32 \\
\hline IBOC & 388 & .20 & .80 & .39 & .09 \\
\hline AQ & 388 & .33 & .75 & .63 & .03 \\
\hline Size & 388 & 15.20 & 33.19 & 27.95 & 2.00 \\
\hline ROA & 388 & -882.28 & 28.15 & -1.86 & 44.88 \\
\hline Growth & 388 & -34.51 & 1317.53 & 6.91 & 69.68 \\
\hline DER & 388 & -.01 & 40.21 & .86 & 2.29 \\
\hline COE & 388 & -10.37 & 14.82 & 1.16 & 2.82 \\
\hline FV & 388 & .11 & 741.00 & 19.21 & 90.36 \\
\hline
\end{tabular}

Note: PP: Customer prespective, PPI: Internal process prespective, PPP: Learning and growth prespective Q: Audit Quality, SIZE: Firm Size, DER: Debt to Equity Ratio, ROA: Return On Assets, COE: Cost of Equity, FV: Firm Value

Table 1 shows the minimum value of the customer perspective variable is -0.99 , the maximum is 18.18 , the average is 0.23 , and the standard deviation is 1.28 . For internal process perspective variables, the minimum value is 4.51 , the maximum is 29.79 , the average is 20.79 , and the 
standard deviation is 2.02. Furthermore, the minimum value of the learning and growth perspective variable is 0.00 , the maximum is 1.27 , the average is 0.41 , and the standard deviation is 0.32 . The independent board of commissioner variable, the minimum value is 0.20 , the maximum is 0.80 , the average is 0.39 , and the standard deviation is 0.32 . In the audit quality variable, the minimum value is 0.33 , the maximum is 0.75 , the average is 0.63 , and the standard deviation is 0.03 . The minimum value for variable size is 15.20 , the maximum is 33.19 , the average is 27.95 , and the standard deviation is 2.00 . The ROA variable has a minimum value of -882.28 , a maximum of 28.15 , an average of -1.86 , and a standard deviation of 44.88 . For growth variables, the minimum value is -34.51 , the maximum is 1317.53 , the average is 6.91 , and the standard deviation is 69.68 . For the DER variable, the minimum value is -0.01 , the maximum is 40.21 , the average is 0.86 , and the standard deviation is 2.29 . The minimum value of the COE variable is 10.37 , the maximum is 14.82 , the average is 1.16 , and the standard deviation is 2.82 . The last, for firm value variables, the minimum value is 0.11 , the maximum is 741.00 , the average is 19.21 , and the standard deviation is 90.36 .

\section{Hypothesis Testing Results}

The results of testing the effect of non-financial measures, independent board of commissioners, and audit quality on firm value with the cost of equity as a moderating variable can be seen in table 2 .

Table 2. Pengaruh Non Financial Measures, Independent Board Of Commisioner dan Audit Quality Terhadap Firm Value Dengan Cost Of Equity Sebagai Variabel Moderating

\begin{tabular}{|c|c|c|c|c|c|}
\hline \multirow{2}{*}{ Variables } & \multirow{2}{*}{ Predictions } & \multirow{2}{*}{ Coefficients } & \multirow{2}{*}{ p-value } & \multicolumn{2}{|c|}{ Collinearity } \\
\hline & & & & Tolerance & VIF \\
\hline $\mathrm{C}$ & & 3.003 & .000 & & \\
\hline PP & + & 2.965 & $.003^{* *}$ & .934 & 1.071 \\
\hline PPI & + & 18.808 & $.000^{* * *}$ & .966 & 1.036 \\
\hline PPP & + & -0.351 & .726 & .941 & 1.063 \\
\hline IBOC & + & 19.395 & $.000 * * *$ & .949 & 1.054 \\
\hline $\mathrm{AQ}$ & + & 20.752 & $.000^{* * * *}$ & .956 & 1.046 \\
\hline Size & + & 0.356 & .722 & .944 & 1.059 \\
\hline ROA & + & -0.362 & .718 & .966 & 1.035 \\
\hline Growth & + & 18.309 & $.000 * * *$ & .975 & 1.025 \\
\hline DER & + & 0.136 & .892 & .950 & 1.053 \\
\hline $\mathrm{COE}$ & + & 0.503 & .613 & .919 & 1.088 \\
\hline $\mathrm{PP} * \mathrm{COE}$ & + & 19.612 & $.000 * * *$ & & \\
\hline PPI*COE & + & -0.574 & .566 & & \\
\hline PPP*COE & + & -0.771 & .441 & & \\
\hline $\mathrm{IBOC} * \mathrm{COE}$ & + & 19.391 & $.000 * * *$ & & \\
\hline $\mathrm{AQ} * \mathrm{COE}$ & + & -1.191 & .235 & & \\
\hline $\mathrm{R}^{2}$ & & 0.924 & & & \\
\hline Adj. $R^{2}$ & & 0.848 & & & \\
\hline F-Statistic & & 145.27 & & & \\
\hline Prob (F-Statistic) & & $0.000 * * *$ & & & \\
\hline Kolmogorov Smirnov & & 0.200 & & & \\
\hline Durbin Watson & & 1.905 & & & \\
\hline Observation & & 388 & & & \\
\hline *** Significant at le & ficant at lev & & & & \\
\hline
\end{tabular}


European Journal of Business and Innovation Research

Vol.8, No.5,pp1-22, August 2020

Published by ECRTD-UK

Print ISSN: 2053-4019(Print), Online ISSN: 2053-4027(Online)

Table 2 shows that the normalization test results of the regression equation used have a Kolmogorov Smirnov value of 0.2> 0.05. Multicollinearity test results show that the tolerance value of customer perspective variables, internal process perspective, learning and growth perceptive, independent board of commissioner, audit quality, size, ROA, DER and COE have values $>0.10$ and VIF value $<10$. Heteroscedasticity test results indicate that the significance value resulting from the regression equation used is $>0.05$. The results of the coefficient of determination in table 2 show that the value of Adj. $\mathrm{R}^{2}$ is 0.848 . The results of the test of the independent board of commissioners, influence of non-financial measures, and audit quality on firm value with the cost of equity as a moderating variable using partial regression tests are (1) The influence of customer perspective variables on firm value has a regression coefficient of 2.965 with p-value 0,003 (2) Effect of internal process perspective variables on firm value has a regression coefficient of 18,808 with p-value 0,000 (3) Effect of growth and learning perspective variables on firm value has a regression coefficient of $-0,531$ and p-value of 0.726 (4) The influence of the Independent board of commissioner variable on firm value has a regression coefficient of 19.395 and p value 0.000 (5) The influence of the Audit Quality variable on firm value has a regression coefficient of 20.752 and p value 0.000 (6) The influence of moderating cost of equity on customer perspective variables the firm value has a regression coefficient value i 19,612 and p value 0,000 (7) The effect of moderating cost of equity on the internal process perspective variable on firm value has a regression coefficient of -0.574 and $p$ value 0.566 (8) The effect of moderating cost of equity on the growth perspective and learning variables on firm value has regression coefficient value $-0,771$ and $p$ value 0,441 (9) The effect of moderating cost of equity on the independent board of commissioner variable on firm value has a regression coefficient of 19,391 and $p$ value 0,000 (10) The influence of moderating cost of equity on audit quality variables on firm value has a regression coefficient of -1.191 and $p$ value of 0.235 .

\section{DISCUSSION}

\section{Descriptive Statistics.}

Descriptive statistics are used to describe data statistically. Descriptive statistics in this study refer to the mean (mean) and standard savings (standard deviation), the minimum and maximum values as well as from all the variables in a study. Standard deviation is a reflection of the average deviation of data from the mean. Standard deviation can describe how large the variation of data, where the mean value is smaller than if the standard deviation value, the mean value is a poor representation of the overall data. But if the opposite is true, the mean value is a good representation of the overall data. From the results of descriptive statistics in this study shown in table 1 that the results of descriptive statistics on customer perspective variables, ROA variables, growth variables, firm value variables, the average value generated cannot be used to present these variables because the average value < standard deviation value. This shows that these variables have very high data deviations so that the spread of the data does not show abnormal results and causes bias. While the internal process perspective variables, learning and growth perspective variables, independent board of commissioner variables, audit quality variables, size variables, DER variables and COE variables the resulting average values can be used to present these variables because of their average values $>$ values standard deviation. This shows that these variables have low data deviations so that the spread of the data shows normal and unbiased results. 
European Journal of Business and Innovation Research

Vol.8, No.5,pp1-22, August 2020

Published by ECRTD-UK

Print ISSN: 2053-4019(Print), Online ISSN: 2053-4027(Online)

\section{Hypothesys Testing.}

Normalization test results of this study using linear regression equations show normally distributed data that has been obtained, so that the variables used can be used for further testing. Multicollinearity test shows that the dependent, independent and control variables do not occur multicollinearity, because the resulting tolerance value is above 0.10 and the VIF value is below 10. Therefore, there is no multicollinearity problem in the regression model that has been made. In addition, the results of the heteroscedasticity test showed a significance level of $>0.05$ where the assumption that this data variable was heteroscedasticity was met. The influence of the independent variable internal process perspective, customer perspective, learning and growth perspective, independent board of commissioner and audit quality used in this study on the firm value dependent variable is $84.8 \%$ of the coefficient determination test results and the rest is influenced by other variables that are not included in this study.

The partial regression test results in table 2 show that the hypothesis received based on the value of the regression coefficient and $p$-value is the firm value hypothesis positively influenced by the customer perspective, firm value is positively influenced by the perspective of the internal business process firm value is influenced positively by the independent board commissioner, firm value is positively influenced by Audit Quality, and the influence of independent board of commissioner on firm value is weakened by the cost of equity with the magnitude of the regression coefficient and p-value respectively $2.965 ; 0.003,18.808 ; 0,000$, 19,$395 ; 0,000,20,752 ; 0,000,19,391 ; 0,000$. The resulting regression coefficient is directly proportional to the hypothesis of the independent and independent variables and the p-value $<0.05$ and for the addition of moderating variables in accordance with the hypothesis made where the resulting regression coefficient value is smaller than the regression coefficient before moderating and the value $p$-value $<0.05$ as in the independent board of commissioner variable decreased by 0.009 so that the variable cost of equity weakened the independent board of commissioner.

On non-financial disclosure variables that use the balance sorecard, firm value is significantly influenced by customer perspective and internal process perspectives. This means that companies that have a good customer relationship and high customer satisfaction and have a good and good internal business process, can increase the value of the company as in the study of $\mathrm{Wu}$ and Chen (2011) where firm value is positively influenced by the customer's perspective and internal business processes (Wu \& Chen, 2011). Another thing in this study, firm value is also positively influenced by the independent board of commissioners. Manufacturing companies in the 2013-2016 period that had more independent commissioners in the proportion of the board of commissioners, could increase the value of the company. Independent board of commissioner is an independent person who is placed in the position of commissioner of the company and is free from all relationships that can affect the ability and policy of these personnel (Indonesia, 2007). Therefore, if the number of independent board of commissioners is large, the decision taken to increase firm value is stronger, making it more difficult for intervention by interested parties. The results of the research related to the relationship between independent board of commissioner and firm value are the same as those of Kaplan and Reishus (1990) and Millstein and MacAvoy (1998) where the company value increases due to the existence of independent commissioners who have the ability (Kaplan, 2012) and Lamoereaux et. all (2019) where companies implementing Lead Independent Directors (LID) can improve 
firm value and quality of corporate governance (Lamoreaux et al., 2019). In this study, companies that have high audit quality, the firm value is also high. Therefore, firm value in this study is positively influenced by audit quality. The use of high quality auditors will reduce the opportunity for companies to cheat in presenting inaccurate information to the public (MohammadRezaei et al., 2018). Management and economic activities of a company are monitored and evaluated by audit activities (Aobdia, 2019; Appiah, 2020) so that quality audits can improve management activities so as to increase firm value of a company (MohammadRezaei et al., 2018). In this study, the regression coefficient of the independent board of commissioner variables to the firm value moderated by the cost of equity has decreased by 0.009 and significantly affected because the p-value $<0.05$. The rate of return expected by investors when they invest money into the company is the Cost of equity (Koller et al., 2015), therefore investors will intervene in decisions made by the independent board of commissioners in order to get a large return and can affect firm value. This is consistent with research conducted by Guo et. all (2019) where the control of shareholders can increase the value of cost of equity (Guo et al., 2019) but the decision of the independent board of commissioner can be intervened because it will make activities that can increase firm value can be reduced because of the high support needed management systems (Bangmek et al., 2018) and technology (Dow et al., 2017) that can increase firm value.

Based on the results of the partial regression test shown in table 2, the rejected hypothesis is that firm value is positively influenced by the perspective of growth and learning, the customer's prefective influence on firm value is weakened by the Cost of equity, the prefective influence of internal business processes on firm value is weakened by the Cost of equity, the prefective effect of growth and learning on firm value is weakened by the Cost of equity, and the effect of audit quality on firm value is weakened by the Cost of Equity with the magnitude of the regression coefficient and p-value respectively $-0,351 ; 0.726,-0.574 ; 0.566,19,612$; $0,000,-0,771 ; 0,441,-1,191 ; 0.235$. The resulting regression coefficient value is directly and inversely proportional to the hypothesis of the independent variable against the independent, however, the p-value> 0.05 so that the independent variable has no effect on the firm value dependent variable even though the results of the partial regression test are directly proportional to the hypothesis made. Non-financial measures related to the perspective of growth and learning from the value of the regression coefficient has a negative effect on firm value and not significant because the $\mathrm{p}$-value $>0.05$. This shows that increasing the perspective of growth and learning will reduce the value of firm value. In this study, companies that do growth and learning in their companies require quite high financial efforts. This causes the firm value to decrease because the company's financial value decreases because it must be used to finance the company's growth and learning. The results of the growth and learning that is done cannot make the company develop so that in this study the perspective of company growth and learning has a negative effect on firm value. The results of this study contradict the research of $\mathrm{Wu}$ and Chen (2011) where firm value is positively influenced by the growth and learning perspective (Wu \& Chen, 2011). For the customer perspective variable on the non financial disclosure variable, cost of equity as a moderating variable strengthened the customer perspective by 16,647 and had a significant effect while for the internal business process perspective and the growth and learning perspective decreased by 19,382 and 0.42 . This shows that the cost of equity does not weaken all non-financial disclosure variables. Cost of equity strengthens customers' perspectives because with increasing cost of equity proves that the 
company's customers are high so that financials from high companies can provide high cost of equity to be received by shareholders. Instead the cost of equity weakens internal business processes because to improve internal business processes a good management system is needed and this can reduce the value of cost of equity (Bangmek et al., 2018) and the perspective of growth and learning because to increase growth and learning financial needs high level to prepare good facilities and infrastructure and it requires a large financial cost so that it can reduce the value of cost of equity (Dow et al., 2017).

\section{CONCLUCION}

Based on the results of this study it can be concluded that the non-financial disclosure variable consisting of customer perspective and internal business process perspective, independent board commissioner and audit quality significantly influence firm value and cost of equity as a moderating variable weaken the influence of independent board of commissioner on firm value. While the non-financial disclosure variable, namely the perspective of growth and learning, does not significantly affect firm value. For cost of equity as a moderating variable, strengthening the non-financial disclosure variable, namely the customer perspective variable, but the internal business process perspective variable and the growth and learning perspective variable are weakened by the cost of equity. Non financial disclosure variables that affect firm value are the customer perspective and internal business process perspective where the company has a good customer relationship and high customer satisfaction and has a good and good internal business process, can increase company value while the perspective of growth and learning is not affect firm value where growth and learning in the company requires financial effort high enough so as to reduce firm value. The independent board commissioner variable influences firm value because the number of independent board of commissioners has more strengthened the decision making by the independent board of commissioner to carry out activities that can increase firm value and are difficult for intervention by interested parties. Audit quality affects firm value because audit quality can monitor and evaluate management and economic activities of the company reducing the opportunity for companies to cheat in presenting inaccurate information to the public. Cost of equity as a moderating variable in this study strengthens the customer perspective of non-financial disclosure variables and significantly influences due to an increase in the number of customers in the company which will increase the amount of cost of equity. Another thing, the cost of equity weakens business processes and the perspective of growth and learning on non-financial disclosure variables because this perspective requires a good system and infrastructure so as to reduce the value of cost of equity. The cost of equity also weakens the independent board of commissioner and audit quality because interventions that can weaken the policies made and monitoring and evaluation that occur does not become weak and can cause community information is not in accordance with reality. This can weaken firm value.

\section{REFERENCE}

Aguir, I., \& Aguir, W. (2019). Director and officer liability protection and firm value: Unintended consequences. Finance Research Letters, (February), 1-9. https://doi.org/10.1016/j.frl.2019.04.033

Agustina, C., \& Ardiansari, A. (2015). Pengaruh Faktor Ekonomi Makro Dan Kinerja 
European Journal of Business and Innovation Research

Vol.8, No.5,pp1-22, August 2020

Published by ECRTD-UK

Print ISSN: 2053-4019(Print), Online ISSN: 2053-4027(Online)

Keuangan Terhadap Nilai Perusahaan. Management Analysis Journal, 4(1), 10-21. https://doi.org/10.15294/maj.v4i1.7203

Ahmad, K., \& Zabri, S. M. (2016). The Application of Non-Financial Performance Measurement in Malaysian Manufacturing Firms. Procedia Economics and Finance, 35(October 2015), 476-484. https://doi.org/10.1016/s2212-5671(16)00059-9

Alifani, G. A., \& Nugroho, A. B. (2019). Proving Modigliani and Miller Theories of Capital Structure: The Research on Indonesia's Cigarette Companies. SSRN Electronic Journal, (May 2018). https://doi.org/10.2139/ssrn.3393045

Amin, A., Djuminah, D., \& Suhardjanto, D. (2017). Board-Auditor Interaction and Earnings Management : The Model of Company with Concentrated Ownership. Review of Integrative Business and Economics Research, 6(3), 217-238.

Andrianto, Y., \& Mirza, A. R. (2016). A Testing of Efficient Markets Hypothesis in Indonesia Stock Market. Procedia - Social and Behavioral Sciences, 219, 99-103. https://doi.org/10.1016/j.sbspro.2016.04.048

Aobdia, D. (2019). Do practitioner assessments agree with academic proxies for audit quality? Evidence from PCAOB and internal inspections. Journal of Accounting and Economics, 67(1), 144-174. https://doi.org/10.1016/j.jacceco.2018.09.001

Appiah, B. A. (2020). Does the severity of a client's negative environmental, social and governance reputation affect audit effort and audit quality? Journal of Accounting and Public Policy, (March 2011), 106713. https://doi.org/10.1016/j.jaccpubpol.2019.106713

Asti Awalia, D. (2014). Pengaruh Risiko Litigasi Terhadap Kualitas Pelaporan Keuangan dengan Keahlian Hukum Komite Audit sebagai Variabel Pemoderasi (Studi pada Perusahaan Manufaktur Yang Terdaftar Di Bursa Efek Indonesia Periode 2010-2012). 2014, 1-13. Retrieved from https://ejournal3.undip.ac.id/index.php/accounting/article/view/6051/5839

Azizkhani, M., Daghani, R., \& Shailer, G. (2018). Audit Firm Tenure and Audit Quality in a Constrained Market. International Journal of Accounting, 53(3), 167-182. https://doi.org/10.1016/j.intacc.2018.07.002

Bangmek, R., Yodbutr, A., \& Thanjunpong, S. (2018). Cost of equity and disclosure of management's responsibility for financial reports of firms in Thailand. Kasetsart Journal of Social Sciences. https://doi.org/10.1016/j.kjss.2018.08.005

Bhandari, V., Rose, S., \& Wilson, E. J. (2019). Non-financial barriers to combined heat and power in the United States - A qualitative study. Electricity Journal, 32(3), 49-56. https://doi.org/10.1016/j.tej.2019.02.011

Boubaker, S., Boubakri, N., Grira, J., \& Guizani, A. (2018). Sovereign wealth funds and equity pricing: Evidence from implied cost of equity of publicly traded targets. Journal of Corporate Finance, 53, 202-224. https://doi.org/10.1016/j.jcorpfin.2018.10.007

Breuer, W., Müller, T., Rosenbach, D., \& Salzmann, A. (2018). Corporate social responsibility, investor protection, and cost of equity: A cross-country comparison. Journal of Banking and Finance, 96, 34-55. https://doi.org/10.1016/j.jbankfin.2018.07.018

Cavaco, S., Crifo, P., Rebérioux, A., \& Roudaut, G. (2017). Independent directors: Less informed but better selected than affiliated board members? Journal of Corporate Finance, 43, 106-121. https://doi.org/10.1016/j.jcorpfin.2017.01.004

Christiani, I., \& Nugrahanti, Y. W. (2014). Pengaruh Kualitas Audit Terhadap Manajemen Laba. Jurnal Akuntansi Dan Keuangan, 16(1), 52-62. 
European Journal of Business and Innovation Research

Vol.8, No.5,pp1-22, August 2020

Published by ECRTD-UK

Print ISSN: 2053-4019(Print), Online ISSN: 2053-4027(Online)

https://doi.org/10.9744/jak.16.1.52-62

Connelly, B. L., Certo, S. T., Ireland, R. D., \& Reutzel, C. R. (2011). Signaling theory: A review and assessment. Journal of Management, 37(1), 39-67.

https://doi.org/10.1177/0149206310388419

Dananjaya, D., \& Agus Ardiana, P. (2016). Proporsi Dewan Komisaris Independen Sebagai Pemoderasi Pengaruh Kepemilikan Institusional Pada Manajemen Laba. E-Jurnal Akuntansi, 15(2), 1595-1622.

Dickins, D., Johnson-Snyder, A. J., \& Reisch, J. T. (2018). Selecting an auditor for Bradco using indicators of audit quality. Journal of Accounting Education, 45(August 2017), 32-44. https://doi.org/10.1016/j.jaccedu.2018.07.001

Dow, K. E., Watson, M. W., \& Shea, V. J. (2017). Riding the waves of technology through the decades: The relation between industry-level information technology intensity and the cost of equity capital. International Journal of Accounting Information Systems, 25(October 2016), 18-28. https://doi.org/10.1016/j.accinf.2017.03.001

Falah, N. H., \& Meiranto, W. (2017). Pengaruh Pengungkapan Intellectual Capital Terhadap Biaya Modal Ekuitas (Studi Kasus pada Perbankan). Diponegoro Journal of Accounting, 6(4), 462-472.

Fan, Y., Boateng, A., King, T., \& MacRae, C. (2019). Board-CEO friendship ties and firm value: Evidence from US firms. International Review of Financial Analysis, 65(February), 101373. https://doi.org/10.1016/j.irfa.2019.101373

Fu, L., Parkash, M., \& Singhal, R. (2017). Tobin's q Ratio and Firm Performance. International Research Journal of Appllied Finance, (June). https://doi.org/10.0704/article-2

Grundy, Q., Mayes, C., Holloway, K., Mazzarello, S., Thombs, B. D., \& Bero, L. (2019). Conflict of interest as ethical shorthand: Understanding the range and nature of "nonfinancial conflict of interest" in biomedicine. Journal of Clinical Epidemiology. https://doi.org/10.1016/j.jclinepi.2019.12.014

Gumanti, T. A., Nastiti, A. S., \& Lestari, A. R. (2016). Good corporate governance and earnings management in indonesian initial public offerings. Corporate Ownership and Control, 13(4), 558-565. https://doi.org/10.22495/cocv13i4c4p5

Gumanti, T. A., \& Prasetiawati, W. (2012). Board of Commisioner Duality Role, Governance and Earnings Management of Initial Public Offerings in Indonesia. Jurnal Akuntansi Dan Keuangan, 13(2). https://doi.org/10.9744/jak.13.2.80-86

Guo, J., Li, C., Jiao, W., \& Wang, Z. (2019). Marketisation, information transparency and the cost of equity for family firms. Finance Research Letters, 101394. https://doi.org/10.1016/j.frl.2019.101394

Gupta, A., Raman, K., \& Shang, C. (2018). Social capital and the cost of equity. Journal of Banking and Finance, 87, 102-117. https://doi.org/10.1016/j.jbankfin.2017.10.002

Gupta, K., Krishnamurti, C., \& Tourani-Rad, A. (2018). Financial development, corporate governance and cost of equity capital. Journal of Contemporary Accounting and Economics, 14(1), 65-82. https://doi.org/10.1016/j.jcae.2018.02.001

Handriani, E., \& Robiyanto, R. (2018). Corporate Finance and Firm Value in The Indonesian Manufacturing Companies. International Research Journal of Business Studies, 11(2), 113-127. https://doi.org/10.21632/irjbs.11.2.113-127

Hanim, F., Rauf, A., Johari, N. H., Buniamin, S., Raida, N., \& Rahman, A. (2008). The Impact of Company and Board Characteristics on Earnings Management : Evidence 
European Journal of Business and Innovation Research

Vol.8, No.5,pp1-22, August 2020

Published by ECRTD-UK

Print ISSN: 2053-4019(Print), Online ISSN: 2053-4027(Online)

from Malaysia Fatimah Hanim Abdul Rauf, Nor Hasimah Johari, Sharifah Buniamin and. (December 2014).

Harasztosi, P., \& Kátay, G. (2017). Currency matching and carry trade by non-financial corporations. Journal of Banking and Finance, 40. https://doi.org/10.2760/936295

Hartmann-Tews, I., Bartsch, F., Wagner, I., \& Rulofs, B. (2019). Managing prevention of sexual violence and the role of commissioners in national sport federations in Germany. Sport Management Review. https://doi.org/10.1016/j.smr.2019.09.006

Huang, H. C., Chu, W., \& Wang, W. K. (2007). Strategic performance measurement and value drivers: Evidence from international tourist hotels in an emerging economy. Service Industries Journal, 27(8), 1111-1128. https://doi.org/10.1080/02642060701673778

Imamah, N., Lin, T. J., Suhadak, Handayani, S. R., \& Hung, J. H. (2019). Islamic law, corporate governance, growth opportunities and dividend policy in Indonesia stock market. Pacific Basin Finance Journal, 55(February), 110-126. https://doi.org/10.1016/j.pacfin.2019.03.008

Indonesia, P. R. (2007). Undang - undang Republik Indonesia Nomor 40 Tahun 2007 Tentang Perseroan Terbatas.

Indriyani, E. (2017). Pengaruh Ukuran Perusahaan dan Profitabilitas Terhadap Nilai Perusahaan. Akuntabilitas, 10(2), 333-348. https://doi.org/10.15408/akt.v10i2.4649

Jao, R., \& Pagalung, G. (2011). Corporate Governance, Ukuran Perusahaan, dan Leverage Terhadap Manajemen Laba Perusahaan Manufaktur Indonesia. Jurnal Akuntansi \& Auditing, 8(1), 43-54.

Johnston, D. J. (2004). OECD principles of corporate governance. In Principes de gouvernement d'entreprise de l'OCDE 2004. https://doi.org/10.1007/978-4-431-309208_10

Kaplan, R. S. (2012). Conceptual Foundations of the Balanced Scorecard. SSRN Electronic Journal. https://doi.org/10.2139/ssrn.1562586

Kaplan, R. S., \& Norton, D. P. (2001). Transforming the Balanced Scorecard from Performance Measurement to Strategic Management: Part I. Accounting Horizons, 15(1), 87-104.

Khaoula, F., \& Moez, D. (2019). The moderating effect of the board of directors on firm value and tax planning: Evidence from European listed firms. Borsa Istanbul Review, 19(4), 331-343. https://doi.org/10.1016/j.bir.2019.07.005

Kirana, P. A. A. (2013). Pengaruh Kualitas Audit terhadap Cost Of Equity Capital ( Studi Empiris pada Perusahaan yang Terdaftar di Bursa Efek Indonesia Tahun 2011 ) (Vol. 2).

Koller, T., Goedhart, M., \& Wessels, D. (2015). Measuring and Managing the Value of Companies. In McKinsey \& Company (Vol. 53). https://doi.org/10.1017/CBO9781107415324.004

Kooli, C. (2019). Governing and managing higher education institutions: The quality audit contributions. Evaluation and Program Planning, 77(September), 101713. https://doi.org/10.1016/j.evalprogplan.2019.101713

Kovermann, J., \& Velte, P. (2019). The impact of corporate governance on corporate tax avoidance - A literature review. Journal of International Accounting, Auditing and Taxation, 36, 100270. https://doi.org/10.1016/j.intaccaudtax.2019.100270

Lai, K. W. (2019). Audit report lag, audit fees, and audit quality following an audit firm merger: Evidence from Hong Kong. Journal of International Accounting, Auditing and 
European Journal of Business and Innovation Research

Vol.8, No.5,pp1-22, August 2020

Published by ECRTD-UK

Print ISSN: 2053-4019(Print), Online ISSN: 2053-4027(Online)

Taxation, 36, 100271. https://doi.org/10.1016/j.intaccaudtax.2019.100271

Lamoreaux, P. T., Litov, L. P., \& Mauler, L. M. (2019). lead Independent Directors : Good governance or window dressing? Journal of Accounting Literature, 43(June), 47-69. https://doi.org/10.1016/j.acclit.2019.06.001

Likitwongkajon, N., \& Vithessonthi, C. (2020). Do foreign investments increase firm value and firm performance? Evidence from Japan. Research in International Business and Finance, 51(September 2019), 101099. https://doi.org/10.1016/j.ribaf.2019.101099

Lord, B. R., Shanahan, Y. P., \& Gage, M. J. (2006). The Balanced Scorecard: A New Zealand Perspective. Pacific Accounting Review, 17(1), 49-77.

Makonah, Cahaya, Y. F., \& Riwayati, H. E. (2016). The Effect of Banking Company Performance Toward Good Corporate Governance Listed in Indonesia Stock Exchange. Social and Behavioral Sciences, 219, 486-492. https://doi.org/10.1016/j.sbspro.2016.05.024

MohammadRezaei, F., Mohd-Saleh, N., \& Ahmed, K. (2018). Audit Firm Ranking, Audit Quality and Audit Fees: Examining Conflicting Price Discrimination Views. International Journal of Accounting, (xxxx), 1-19. https://doi.org/10.1016/j.intacc.2018.11.003

Murwaningsari, E. (2009). Hubungan Corporate Governance, Corporate Social Responsibilities dan Corporate Financial Performance Dalam Satu Continuum. Jurnal Akuntansi Dan Keuangan, 11(1), 30-41. https://doi.org/10.9744/jak.11.1.pp.30-41

Nafisah, L., \& Meiranto, W. (2017). Pengaruh Karakteristik Perusahaan Terhadap Pengungkapan Modal Intelektual Dalam Prospektus. Diponegoro Journal of Accounting, 6(3), 1-11.

Nurjanati, R., \& Rodoni, A. (2015). Pengaruh Asimetri Informasi Dan Tingkat Disclosure Terhadap Biaya Ekuisitas Dengan Kepemilikan Manajerial Sebagai Variabel Moderating (Studi Empiris Pada Perusahaan Manufaktur Di Bursa Efek Indonesia). Jurnal Bisnis Dan Manajemen, 5(2), 173-190.

Okoye, E. I., Odum, A. N., \& Odum, C. G. (2017). Effect of Balanced Scorecard On Firm Value: The Case Of Quoted Manufacturing Companies In Nigeria. International Conference On African Entrepreneurship and Innovation for Sustainable Develoment (AEISD).

Ongkowibowo, D. T., \& Hatane, S. E. (2015). Pengaruh Marketing Activity Terhadap Profitability dan Market Value Perusahaan Retail dan Produksi Besar. Business Accounting Review, 3(1), 362-373.

Pacheco-de-Almeida, G., Hawk, A., \& Yeung, B. (2007). Speed and Tobin 's q. The Rand Journal of Economics, 19(4), 1-51. https://doi.org/10.1007/s11142-013-9275-2

Peda, P., \& Vinnari, E. (2019). The discursive legitimation of profit in public-private service delivery. Critical Perspectives on Accounting, (xxxx). https://doi.org/10.1016/j.cpa.2019.06.002

Rabo, J. (2014). A Study on Effect of Non-Financial Balanced Scorecard Perspectives on Financial Performance of Property Firms Listed in the Philippine Stock Exchange. Journal of Global Business, 3(1), 13-18.

Rahayu, M., \& Sari, B. (2018). Faktor-Faktor Yang Mempengaruhi Nilai Perusahaan. Jurnal Analisis Bisnis Ekonomi, 16(1), 19-25. https://doi.org/10.31603/bisnisekonomi.v16i1.2127

Rodriguez-Fernandez, M. (2016). Social responsibility and financial performance: The role 
European Journal of Business and Innovation Research

Vol.8, No.5,pp1-22, August 2020

Published by ECRTD-UK

Print ISSN: 2053-4019(Print), Online ISSN: 2053-4027(Online)

of good corporate governance. BRQ Business Research Quarterly, 19(2), 137-151. https://doi.org/10.1016/j.brq.2015.08.001

Sabrin, Sarita, B., Takdir, D., \& Sujono. (2016). The Effect of Profitability on Firm Value in Manufacturing Company at Indonesia Stock Exchange. The International Journal of Engineering and Science (IJES), 5(10), 81-89. https://doi.org/10.1016/00144827(80)90264-5

Sari, P. A. (2009). Pengaruh Struktur Corporate Governance Terhadap Cost of Equity Capital.

Setiadi, I., Rahmawati, Suhardjanto, D., \& Djuminah. (2017). Board Independence , Environmental Disclosure, and Firm Value. Review of Integrative Business and Economics Research, 6(4), 409-417.

Sharma, S. S., Thuraisamy, K., Madyan, M., \& Laila, N. (2019). Evidence of price discovery on the Indonesian stock exchange. Economic Modelling, 83(August), 2-7. https://doi.org/10.1016/j.econmod.2019.09.005

Singh, A., Singh, H., Sultana, N., \& Evans, J. (2019). Independent and joint effects of audit partner tenure and non-audit fees on audit quality. Journal of Contemporary Accounting and Economics, 15(2), 186-205. https://doi.org/10.1016/j.jcae.2019.04.005

Skaife, H. A., Collins, D. W., \& LaFond, R. (2011). Corporate Governance and the Cost of Equity Capital. SSRN Electronic Journal, (December). https://doi.org/10.2139/ssrn.639681

Sofia, I. P. (2019). The Role of Corporate Diversification, Capital Structure Determinant, And Structure of Ownership on Earning Management with Information Asymmetry as Moderating Variable. Research Journal of Finance and Accounting, 10(14), 45-51. https://doi.org/10.7176/rjfa/10-14-05

Soleman H. Abdul Kahar. (2008). Kepemilikan Manajerial Terhadap Kebijakan Pendanaan dan Dividen. Journal of Business Administration, 12(3), 12-22.

Tan, J., Yan, L., \& Chan, K. C. (2019). The impact of the logistics service standardization on firm value: Evidence from China. North American Journal of Economics and Finance, (January), 101134. https://doi.org/10.1016/j.najef.2019.101134

Titko, J., \& Shina, I. (2017). Non-financial Value Drivers: Case of Latvian Banks. Procedia Engineering, 178, 192-199. https://doi.org/10.1016/j.proeng.2017.01.095

Tulli, M. M. (2014). Auditing Practices and Organizational Efficiency in Local Government Authorities: A Case Study of Tanzania. Journal of Finance and Accounting, 2(4), 100 114. https://doi.org/10.12691/jfa-2-4-3

Utomo, N. A. (2016). Faktor-Faktor yang Mempengaruhi Nilai Perusahaan pada Perusahaan Indeks LQ45 Di Bursa Efek Indonesia. Dinamika Akuntansi, Keuangan Dan Perbankan, 5(1), 82-94. https://doi.org/1979-4878

Vintilă, G., \& Gherghina, Ş. C. (2013). Board of directors independence and firm value: Empirical evidence based on the Bucharest stock exchange listed companies. International Journal of Economics and Financial Issues, 3(4), 885-900.

Wati, G. dan, \& Putra, I. wayan. (2017). Corporate Governance Pada Kualitas Laba. 19, 137-167.

Wibisono, D. A., \& Handayani, K. (2015). Pemilihan saham yang optimal menggunakan Capital Asset Pricing Model (CAPM). Jurnal Manajemen \& Kewirausahaan, 5(1), 32 46.

Wu, S. I., \& Chen, J. H. (2011). Comparison between manufacturing companies that are ISO 
European Journal of Business and Innovation Research

Vol.8, No.5,pp1-22, August 2020

Published by ECRTD-UK

Print ISSN: 2053-4019(Print), Online ISSN: 2053-4027(Online)

certified and those that are not certified using performance measurement model. Total Quality Management and Business Excellence, 22(8), 869-890.

https://doi.org/10.1080/14783363.2011.593860

Wulandari, N. (2006). Pengaruh Indikator Mekanisme Corporate Governance Terhadap Kinerja Perusahaan Publik Di Indonesia (The Influence of Corporate Governance Mechanism Indicator to Public Company Performance in Indonesia). Fokus Ekonomi, 1(2), 120-136.

Zhu, J., Ye, K., Tucker, J. W., \& Chan, K. (Johnny) C. (2016). Board hierarchy, independent directors, and firm value: Evidence from China. Journal of Corporate Finance, 41, $262-$ 279. https://doi.org/10.1016/j.jcorpfin.2016.09.009

Zuhroh, I. (2019). The Effects of Liquidity, Firm Size, and Profitability on the Firm Value with Mediating Leverage. KnE Social Sciences, 3(13), 203. https://doi.org/10.18502/kss.v3i13.4206

Zulfikar, R., May, N., Suhardjanto, D., \& Agustiningsih, S. W. (2017). Independent Commissioner Against Mandatory Disclosure of Financial Performance as a Moderating Variable. Review of Integrative Business and Economics Research, 6(3), 205-216. Retrieved from http://ezproxy.fiu.edu/login?url=https://search.proquest.com/docview/1918329182?acco untid=10901 http://resolver.ebscohost.com/openurl?ctx_ver=Z39.882004\&ctx_enc=info:ofi/enc:UTF8\&rfr_id=info:sid/ProQ\%3Ascitechpremium\&rft_val_fmt=info:ofi/fmt:kev:mtx:jou 